\title{
Building terminological competence in ecology students through creation of glossaries
}

\author{
Irina Kulamikhina ${ }^{1, *}$, Ekaterina Abrosimova ${ }^{1}$, Zhanbota Esmurzaeva ${ }^{1}$ and Jacopo Vigna-Taglianti ${ }^{2}$ \\ ${ }^{1}$ Foreign Languages Department, Omsk State Agrarian University named after P.A. Stolypin, 644008, 1, Institutskaya ploshchad str., \\ Russia. \\ ${ }^{2}$ Foreign Languages Department, Russian State Agrarian University. Moscow Timiryazev Agricultural Academy, 127550, 49, \\ Timiryazevskaya st., Moscow, Russia
}

\begin{abstract}
The present study deals with the problem of development of terminological competence in students in professional ecological education by means of creation of students' glossaries. The authors describe specifics of terminological competence of future ecologists as the ability to competently use terminology in the field of environmental protection, inspection and management to solve academic, research and environment-related tasks by means of communication. The authors develop an original conceptual model of the student's glossary that makes it possible to improve students' knowledge and understanding of professional terminology and lead to their professional and cultural development. The use of international term elements of Latin and ancient Greek origin in the student's glossary solves the problem of ecological terminological ambiguity and promotes internalization of the professional knowledge and development of terminological competence in ecologist students. In ecological education, the student's glossary is a systematizing multilingual and multifunctional open-type list of international term elements, terms and terminological phrases related to ecological sciences, with a possibility to be modified or added with new terms in accordance with the stages and goals of professional training. The specifics and roles of the student's glossary are described at different stages of professional training. The authors formulate the basic principles and requirements for the creation of the student's glossary.
\end{abstract}

\section{Introduction}

In professional ecological education, much attention should be paid to terminological training of students due to the complexity and richness of ecological terminology. According to K. Hodges, many ecological terms have multiple meanings and they could be similar to each other, which leads to a great deal of confusion and impedes environmental problem solving and decision making [5]. Moreover, there is a regular redefinition of ecological terminology across disciplines; this process is complicated with synonymy and polysemy of terms while fundamental terms and the theories behind them are overlooked. These factors cause research problems, misunderstanding and miscommunication among ecologists and with the public [4]. To address challenges associated with the ecological terminological ambiguity, we propose the development of terminological competence in undergraduate and postgraduate students majoring environmental sciences as a most important goal in professional ecological education. A key instrument in the development of ecological terminological competence is creation of glossaries by students in the process of professional training.
A student's glossary is a list of specialized terms in any branch of science with definitions and sometimes equivalents in other languages, purposefully made by students [2]. Students' glossaries perform specialized educational functions in the process of study and do not duplicate the functions of specialist dictionaries and glossaries. They are oriented toward interdisciplinary concerns, and directed to help students study professionrelated terminology in the formal educational system. They can be used as teaching materials in the terminological training of undergraduates. In the learning environment, glossaries can be a source of new scientific knowledge. For graduate students, glossaries can be objects of scientific research and discussion. Also, they can be an obligatory part of student assessment procedures. For practitioners, a glossary becomes a tool for professional development or refreshing certain terminological areas due to the flexibility of terminological systems, when some terms become obsolete and there is a need in updating terminology [10]. At all stages of professional training, creation of glossaries aims to form and develop the conceptual apparatus of the profession [7], which is, in our opinion, the basic component of terminological competence. This specific activity promotes

\footnotetext{
Corresponding author: author@e-mail.org
} 
comprehension, systematization and refreshing of scientific knowledge [8].

\subsection{Purpose of the study}

The purpose of the study is to substantiate and develop a conceptual model of the student's glossary that contributes to the development of terminological competence in students at all stages of professional training. The study is based on the idea that creation of the student's glossary will promote the development of terminological competence in students if the glossary 1) meets learning objectives of professional training; 2) performs several functions in terminological training; 3 ) includes terms and Latin/Greek term elements belonging to a specific subject area.

In accordance with the purpose of the study, we are going to solve the following tasks:

1. to define the concept of terminological competence of an ecologist student;

2. to describe the main characteristics and functions of the student's glossary in the educational process;

3. to define the basic principles of selection and systematization of terms in the student's glossary;

4. to work out requirements for the creation of the student's glossary.

\subsection{Materials and methods}

In order to fulfill the research tasks, the following research methods and approaches are used in the study: theoretical analysis of scientific literature on the research problem; a systematic approach to the description of terminological competence with reference to the environmental sciences. Also, a modeling method allows the development of a conceptual model of an educational glossary. The present study is based on the results obtained from our previous study devoted to the systemic components of terminological training in universities [9]. Methodologically important ones for our study are the ideas about the terminological competence of a specialist proposed by N.V. Bordovskaya \& E.A. Koshkina [1].

\section{Results and Discussion}

According to N.V. Bordovskaya \& E.A. Koshkina [1], terminological competence is defined as an "ability" and "readiness" to use terminology while solving professional problems by means of communication. With reference to ecological education, terminological competence of future ecologists is viewed as the ability to competently use terminology in the field of environmental protection, inspection and management to solve academic, research and environment-related tasks by means of communication. The environment-related conceptual apparatus is at the core of the competence. Based on N.V. Bordovskaya \& E.A. Koshkina's terminological competence framework consisting of the three components (informational, practical and reflective) [1], we suggest that the informational component is represented by the knowledge of terminology related to ecological issues, which makes the basis of conceptual apparatus of a future ecologist. The practical component includes skills of effective practical application of ecological terminology in academic, research and environmental contexts. The reflexive component is represented by students' attitudes, intentions and motives to develop and update their conceptual apparatus for continuous professional self-improvement. Being an integral part of professionalism, terminological competence of a future ecologist incorporates awareness and understanding of terms and concepts in the environmental area in different contexts (academic, scientific, professional) and in different types of communication (oral, written), knowledge of term formation and relationships between the terms, term elements and definitions; skills to apply terminology in all environmental contexts. Especially important is that development of terminological competence needs to be purposefully connected with construction of meaningful knowledge and understanding of terms and their usage in the context. Thus, students' active engagement in the creation of glossaries promotes the effectiveness of the development of terminological competence in ecological education.

There are recently published studies describing the role of activities directed at the creation of glossaries for mastering specialized vocabulary of a particular subject $[3,6,12]$. Previous research findings reveal the distinctive features of the students' glossaries [7,13]; methodology of creation of a student's glossary in the learning process [12]; lexicographic parameters for making glossary entries [13].

In our study we focus on the essential characteristics of the student's glossary, which are:

1. Selectivity. The selection of terms should be purposeful. The sources of ecological terminology should be different types of documentation including regulations, directives, standards, as well as textbooks, periodicals, reports, vocabularies, dictionaries, encyclopedias, etc. The number of terms to be included in the glossary should be limited because working with a large number of terms results in inconsistencies and omissions, and it is very time-consuming.

2. Systematicity. The selected terms shall be wellstructured into terminological systems showing the generic, partitive and associative relations. A diagram or systematic list showing the relationships between the terms or term elements can be used to organize the terminological systems.

3. Multilinguism. The glossary entry should contain information about the etymology of the term which is given in the Latin and ancient Greek languages. The term and its definition should be given in the Russian language. The glossary entry should include information about term equivalents in foreign languages (English or German). Multilingualism of the glossary entry helps students recognize meanings of terms in any professional text in any studied language (Russian, English, German, and Latin). 
4. Multifunctionality. Students' glossaries shall have several different uses. They should provide and systemize information, and educate and motivate students, too. The definition of a term, its equivalents in other languages, term etymology and the relationships between the terms give much information not only about the specific subject area but also about principles and tendencies of scientific naming and patterns of thinking. The student's glossary reflects and fixes the hierarchical relations between terms and groups of terms (partwhole) and syntagmatic relations. For example, ecologist students create glossaries according to different environmental sciences including ecology, biology, chemistry, plant science, zoology, mineralogy and soil science. Then, each of the sciences is divided into the subsections. For example, environmental biology includes biodiversity, evolutionary biology, conservation biology and global climate change. A glossary entry can be made with any lexical unit: a word, a phrase or a term element.

A distinctive feature of the student's glossary is that it is also used for educational purposes. By means of concepts in a lexicographical form, the student's glossary represents the knowledge described in textbooks and scientific papers. It can be used as a tool for studying terminology of certain subject areas or it can be used in the assessment procedures. In postgraduate education, a glossary can become a part or a source of scientific research and discussion. In continuous education, glossaries can be used for further professional development or for updating certain terminological areas.

The motivational function of the student's glossary is associated with specialists' needs for continuous improvement of their professional language and competence through updating terminological knowledge and replenishing glossaries with new terminology.

The goals of the student's glossary should be aligned with the objectives of ecological education which are a balanced development of the professional knowledge (competence), culture and personality of a future ecologist. In our opinion, in the first year of training students should learn about Latin and Greek term elements and the rules of term formation (term formation patterns and spelling rules). Term elements have different semantic specializations (prefixes, suffixes and roots) and, like words, they enter into paradigmatic (synonymy, antonymy, polysemy) and syntagmatic relations. With their unambiguous meaning, frequent and conventional usage, term elements form a most important fund of scientific knowledge which is in the basis of general cultural development of any professional. The knowledge about term elements is of crucial importance for the internalization of the professional knowledge and building a holistic professional worldview in future ecologists.

Here is a fragment of the glossary work concerning one of the term elements - the prefix SYM-/ SYN-made by a $1^{\text {st }}$-year ecologist student in the Professional Communication class

SYM-/ SYN - the Greek prefix, with the meaning of connection, joint action or fusion of something.
Symbiosis (sym- + Greek bios - life, cf. biome) close cohabitation of organisms of different species bringing mutual benefit.

Synanthropic species (syn- + Greek anthropos man, cf. anthropology) - animal species that usually live near human habitation (cockroaches, rats, doves, rooks, etc.).

Synbiology (syn- + Greek bios - life + logos teaching, cf. biology) - a branch of ecology and biocenology that studies the biology and physiology of coenobionts, their biotic relationships.

Syndynamics (syn- + Greek dynamis strength, ability, cf. dynamics) - the dynamics of biocenoses, their variability.

Synoptics (syn- + Greek optikos- related to vision, cf. optical) - a science that studies physical processes in the Earth's atmosphere that determine the future state of the weather.

Synecology (syn- + Greek oikos - house, dwelling, $c f$. ecology) - a branch of ecology that studies the life of communities of organisms (ecosystems, biogeocenoses).

Synergism (syn- + Greek ergon - work, $c f$. ergonomics) - 1) an increase (or decrease) in the force of influence of one factor in the presence of another (or several); 2) the interaction of factors, in which the effect is greater than the sum of the action of individual factors.

See DIA - Greek prefix with the meaning "separation".

Completing this fragment of the glossary, students learn to recognize the term element not only as part of the term itself, but in common words (synthesis, symbol). By giving examples of the use of just one prefix, they learn a large number of new term elements that are necessary in further work. By making a glossary of terms at the early stage of training, students begin to understand how term elements function. Also, they learn the basic laws of the science they are studying.

In the final year of university studies, students have internship and do research work in a specialized branch of ecology. This work promotes mastery of specialized terminology of a particular subject. The selection and fixation of terminology are done in the process of studying professional texts (regulatory documents, guidelines, standards, periodicals). At this stage glossaries become a kind of reference materials. Studying a certain discipline under the guidance of a teacher, a student makes a basic list of terms, establishes their etymology with reference to a glossary of term elements. An example of a student's glossary work on environmental terms containing a term element of Greek origin TROPHE which means "food".

Saprotrophs (from the Greek sapros - rotten, dead + trophe) - organisms that feed on organic matter from dead bodies or animal excrement. Sapropel, saprophage, saprophytes.

Eutrophication of water bodies, eutrophication (from the Greek eu - good + trophe) - an increase in the biological productivity of water bodies as a result of the accumulation of nutrients in the water. Eucalyptus, eutrophs, eukaryotes.

Autotrophs (from the Greek autos - itself + trophe) organisms that independently produce complex organic 
substances. They are divided into phototrophs and chemotrophs. Autogamy, autogenous, autoimmune.

Phototrophs (from the Greek phos, photos - light + trophe) - autotrophic plant organisms capable of photosynthesis. Photon, phosphorus, photography.

Chemotrophs (from the Greek chemeia - chemistry and + trophe) - autotrophic microorganisms that synthesize organic substances from inorganic ones due to the oxidation of the latter. Chemosynthesis, chemotaxis.

Trophobiosis (trophe + Greek bios - life) - a form of symbiosis in which one organism receives nutrients from another (trophobiont) without harming it. Symbiosis, biolocation, biomechanics, bionics.

In postgraduate studies, ecologist students improve their terminological competence mastering professionrelated scientific terminology in the area of their narrow specialization. Students deal with monographs, dissertations, scientific articles in the Russian and foreign languages for selection of terms. For example, in the EFL classroom ecologist students created a glossary to master scientific terminology related to the topic "Biomonitoring and bioindicators of aquatic ecosystems". The source for selection of terms was the research paper [11]. Systematization of the selected terms in the glossary was done on the basis of the categorical analysis. The selection and systematization of terms had the following sequence of actions: 1 . fixation of terms related to the subject area according to the criteria of frequency and prevalence; 2 . selection of generic terms from the list; 3 . building the structure of relations between generic and specific terms on the basis of categorical analysis. The following generic terms were selected in the subject area of bioindication and biomonitoring: function (biomonitoring functions), object (bioindicators), subject (pollutants, bioindication parameters), method (indication methods). Here is a fragment of the categorization-based model of terminology:

Biomonitoring functions are signal function, prediction function, control function, scientific research function.

Bioindicators are aquatic organisms (species: macroinvertebrates, fish, algae, plants).

Bioindication parameters are population parameters (reproductive success, mortality, size distribution, population extinction, changes in composition, dominance switches); biochemical parameters (hormone levels, enzyme activity, induction of metallothioneins, macromolecules, enzyme induction); morphological parameters (cell and tissue damage, deformities); physiological parameters (avoidance-preference reactions, swimming behavior, feeding behavior, respiration activity, valve movements).

Indication methods are surveillance, laboratory testing, biological monitoring, chemical monitoring, biological early warning system, ecotoxicological methods.

Then, the glossary entries were made and included into the student's glossary in the alphabetical order. The glossary entry was organized on the basis of the wholepart principle in the following order: 1 . A general one- word or multi-word term, an indication of a part of speech, a Russian equivalent, a definition of the term in Russian; 2. Attributive phrases; 3. Phrases of various structures.

Here is an example of a glossary entry:

$$
\text { Bioindication parameters - параметры }
$$

биоиндикации (параметры оценки качества природной среды по состоянию её биоты)

Biochemical - биохимические параметры

enzyme activity - ферментативная активность

enzyme induction - индукция ферментов

hormone level - уровень гормона

metallothioneins induction -

металлотионеинов

macromolecules induction - индукция макромолекул

The work on creation of the glossary contributed to the enrichment and systematization of the specialized knowledge regarding the bioindicators and biomonitoring methods used for the analysis and evaluation of water quality. It is equally important that in the process of working on the glossary, postgraduates mastered terminology in English. In this way, students' glossaries help building links between life sciences and humanities. It means that students' glossaries are useful for the development of professional knowledge and professional culture of ecologist students.

We will try to outline the basic principles of creation of the student's glossary at different stages of professional ecological education.

In ecological education, glossaries should contain Latin/Greek term elements, terms and terminological phrases in their close interconnection. International term elements of Latin or Greek origin play a most important role in the development of terminological competence in ecologists. This knowledge ensures correct understanding and usage of terminology in the professional area and eliminates confusion and misunderstanding in professional communication.

Different languages (native and a foreign language, Latin/ancient Greek) should be used in the glossary entry. The use of Latin/ancient Greek in the description of the etymology of the term ensures the correct understanding of the term. The use of foreign languages in the glossary entry contributes to comprehension of any professional text in both the native and a foreign language.

The glossary shows both paradigmatic and syntagmatic relations between the elements. Making glossaries, students learn the rules of combination of term elements, the compatibility of words in a terminological phrase. They also learn to build a hierarchy of terms, hyper- and hyponymic relations between them, understand terms and term elements with similar and opposite meanings.

The selection of terms for the glossary follows the "generic-specific" principle. At the early stages of professional training, students make glossaries of terms belonging to a general professional area with emphasis on international term elements. Then, while studying specialized disciplines, students focus on concepts and terminology of a particular subject area, and in the 
postgraduate course, students master the newest and specialized terms.

Thus, the creation of glossaries helps students develop the knowledge and understanding of professional terminology, which is the key component of terminological competence. At the same time, this work leads to a cultural development of an ecologist student. In ecological education, the student's glossary is a systematizing multilingual and multifunctional opentype list of terminological elements, terms and terminological phrases related to ecological sciences with a possibility to be modified or added with new terms in accordance with the stages and goals of training.

\section{Conclusion}

The present study deals with the problem of development of terminological competence in students in professional ecological education. Terminological competence of future ecologists is the ability to understand and use terminology in the field of environmental protection, inspection and management to solve academic, research and environment-related tasks. The basic component of terminological competence is the knowledge of the conceptual apparatus of the profession, which can be mastered though a specially organized activity - creation of glossaries by students. The study focuses on theoretical and practical aspects of the problem of creation of the student's glossary.

The analysis of the distinctive features, functional characteristics and principles of structuring a glossary entry allows us to formulate the requirements for the creation of the student's glossary:

- the inclusion of international term elements in the student's glossary;

- the selection of terms in accordance with the goals of professional training;

- the use of several languages (native and a foreign language, Latin/ancient Greek) in the glossary entry;

- the use of paradigmatic and syntagmatic relations between terms included in the glossary.

Thus, the result of our study is the conceptual model of the student's glossary aimed at the development of the ecological terminological competence in students. The student's glossary is a systematizing multilingual and multifunctional open-type list of terminological elements, terms and terminological phrases related to ecological sciences with a possibility to be modified or updated with new terms in accordance with the stages and goals of professional ecological education.

\section{References}

1. N.V. Bordovskaya, E.A. Koshkina, Structural and functional model of terminological competence of a specialist. Bulletin of St. Petersburg State University. Series 16. Psychology. Pedagogy, 4, 97-109 (2016) DOI: 10.21638 / 11701 / spbu16.2016.408

2. B.B. Dubichinsky, Theoretical and practical lexicography. Vienna - Kharkov (1998)
3. S. Galova, K. Klimentova, L. Moravcova, Some remarks on the elaboration of a multilingual specialized dictionary of hippology, XLinguae, 14(2), 22-38 (2021) DOI:

10.18355/XL.2021.14.02.02

4. S. Herrando-Pérez, B. Brook, C. Bradshaw, Clarity and precision of language are a necessary route in ecology. BioScience, 64(5), 373-374 (2014) DOI: 10.1093/biosci/biu050

5. K. Hodges, Defining the problem: terminology and progress in ecology, Frontiers in Ecology and the Environment, 6(1), 35-42 (2008) DOI:10.1890/060108

6. A.Z. Ibatova, I.G. Mukhametgaliyev, New ways of professional language thesaurus formation among students of engineering specialties. XLinguae, 11(4), 22-31 (2018) DOI: 10.18355/XL.2018.11.04.03

7. N.G. Kantysheva, Categorical modeling of the 'environmental audit' term system in a systematizing glossary, Bulletin of Chelyabinsk State University, 34(215). Philology. Art Criticism, 49, 51-54 (2010) Retrieved from https://cyberleninka.ru/article/n/kategorialnoemodelirovanie-terminosistemy-ekologicheskiy-auditv-sistematiziruyuschem-glossarii

8. E.A. Koshkina, Conceptual and terminological apparatus of pedagogy as a subject of historical and pedagogical research. Education and Science, 5, 8395 (2012) Retrieved from https://doi.org/10.17853/1994-5639-2012-5-83-95.

9. I.V.Kulamikhina, E.A. Abrosimova, Zh.B. Esmurzaeva, E.Yu. Kamysheva, The content of terminological training of specialists and its implementation based on the pedagogical technology of scaffolding, Modern problems of science and education, 4, 67 (2020) Retrieved from https://www.elibrary.ru/download/elibrary_43925082 _24270913.pdf

10. S. Mozgovoi, E. Abrosimova, A. Kononov, Is fluid biopsy a biopsy: vocabulary and usage, Virchows Archive, 475, 361-361 (2019)

11. N. Oertel, J. Salánki, Biomonitoring and Bioindicators in Aquatic Ecosystems. In: Ambasht R.S., Ambasht N.K. (eds) Modern Trends in Applied Aquatic Ecology, Springer, Boston, MA. (2003) DOI:10.1007/978-1-4615-0221-0_10

12. T.S. Serova, G.R. Chainikova, Contents of the stageby-stage development of the educational terminological dictionary of thesaurus type, Pedagogical Education in Russia, 2, 143-150. (2015) Retrieved from http://journals.uspu.ru/attachments/article/876/27.pdf

13. V.D. Tabanakova, N.A. Sivakova, Typology of dictionaries today. Vestnik of Tyumen State University, 4, 114-120 (2003) 